\title{
The Effect of Imagery Exercise and Progressive Muscle Relaxation on Anxiety and Concentration in Soccer Athletes
}

\author{
1*Zakir Burhan \& ${ }^{2}$ Lalu Yoga Vandita \\ Program Studi Pendidikan Jasmani, Institut Pendidikan Nusantara Global. Jalan Raya Praya- \\ Mantang km-7. Postal code: 83511, Indonesia \\ *Corresponding Author e-mail: zakirburhan84@gmail.com
}

Received: July 2021; Revised: September 2021; Published: December 2021

\begin{abstract}
This study aims to examine the effect of applying imagery and progressive muscle relaxation exercises on the level of anxiety and concentration in Persatu Darek FC athletes. This study uses a quantitative approach with a quasi experimental design (matching-only design). The research sample consisted of 33 athletes who were divided into 3 groups of athletes (11 athletes in each group), each of which was given a pretest and posttest. The experimental group I was given an imagery exercise program, the experimental group II was given a progressive muscle relaxation exercise program, and the third group was a control (conventional exercise). The test instrument to measure the level of concentration is the grid concentration exercise test, while the anxiety test uses a sport anxiety scale. Data analysis in this study used a different test (t-test) and multivariate analysis of variance. The results of the study showed that there was a significant effect of giving progressive muscle relaxation and imagery exercises to the level of anxiety in soccer players. However, it has no effect on conventional exercise modes. The provision of progressive muscle relaxation and imagery exercises also affects concentration in soccer players, and this does not apply to conventional training modes. In this study, we also found that there was no difference in the effect of the concentration variables and the level of anxiety together. Therefore, it can be concluded that neither of the two methods of mental exercise (imagery and progressive muscle relaxation) has a more effective effect on concentration and anxiety levels. The recommendation from the results of this study is that mental exercise conduction (imagery and progressive muscle relaxation) is very important for soccer players as a non-physical exercise mode that is very useful for reducing anxiety and increasing concentration.
\end{abstract}

Keywords: imagery exercises; progressive muscle relaxation; anxiety level; concentration

How to Cite: Burhan, Z., \& Vandita, L. (2021). The Effect of Imagery Exercise and Progressive Muscle Relaxation on Anxiety and Concentration in Soccer Athletes. Prisma Sains : Jurnal Pengkajian Ilmu dan Pembelajaran Matematika dan IPA IKIP Mataram, 9(2), 220-224. doi:https://doi.org/10.33394/j-ps.v9i2.4280

https://doi.org/10.33394/j-ps.v9i2.4280

Copyright $\odot$ 2021, Burhan \& Vandita This is an open-access article under the CC-BY License.

\section{INTRODUCTION}

In everyday life, humans cannot be separated from sports activities, and there are many kinds of sports that can be chosen to achieve the above goals, both indoor and outdoor, both individually and in teams. Sports that are in the form of team games include football. Football is a team sport that relies on technique, tactics and mentality to get maximum results. Sport is a series of regular and planned physical movements that people do consciously to improve their functional abilities, in accordance with the purpose of doing sports, and to be able to obtain calm and high concentration it is necessary to have mental training (Malm et al., 2019). Therefore, football is a branch that guides its players to have the ability to have a good mental condition. Various forms of emotional turmoil that athletes feel, whether it's happy, sad, angry, or anxious, can affect the condition of concentration and physiological conditions of the body, so that it also affects the physical, mental balance, and appearance of athletes when they jump in the field (Smith et al., 2020). 
Anxiety that does not rule out the possibility of appearing when athletes compete will also greatly affect their ability to perform optimally (Ortega Vila et al., 2020). Anxiety is a negative emotional feeling with nerves, always worried about the activities being carried out (Gao et al., 2021). This can be one of the causes of defeat when competing or competing. Based on several factors that can affect the emotional mental state, mental training is needed, especially in terms of anxiety levels and concentration, which in this case is especially in the sport of football. In addition to anxiety, concentration is one of the mental aspects that is often studied in sports psychology, without high concentration, athletes can do things that can cause them to lose in matches (Benítez-Sillero et al., 2021). Furthermore, there are several mental training techniques that can be used to increase concentration including mindfulness meditation, self-talk training, self-hypnosis, quiet eye training, mind control training, imagery training, progressive muscle relaxation, autogenic training, and goal setting (Arifin, 2018; Izgu et al., 2020; Maharani, 2017). In this study, researchers used mental imagery exercises and progressive muscle relaxation exercises, where this form of mental exercise can be used to increase concentration, especially soccer club athletes.

Imagery training is a form of concentration training in which the athlete is given instructions to imagine, visualize, and bring back the athlete's best performance in his mind (Oh \& Choi, 2021). Imagery training refers to attempts to recreate or re-create an experience in the mind, that is, to create or recreate an experience in the brain (Buck et al., 2016). The process of doing imagery training in its implementation is by remembering or bringing back in his mind the best experiences both during training and during competition in the form of information stored in memory and making it a meaningful image of movement patterns (Lefebvre \& D'Angiulli, 2019). In addition to imagery training, another exercise mode used is progressive muscle relaxation. Progressive muscle relaxation exercise is a form of concentration exercise that involves the muscles of the body directly in the implementation process (Mackereth \& Tomlinson, 2010). The time required to perform progressive muscle relaxation exercises ranges from 20-30 minutes. In each muscle group, the contraction or muscle tension is performed for 2 (two) repetitions. When the muscle contraction is held for 5 seconds, while during relaxation it is held for 5-10 seconds, then proceed to other muscle groups.

Based on the two training modes as described, this study aims to examine the effect of applying imagery and progressive muscle relaxation exercises on the level of anxiety and concentration in Persatu Darek FC athletes.

\section{METHOD}

This study uses a quantitative approach with a quasi experimental design (matchingonly design), as presented in Table 1.

Table 1. Research design

\begin{tabular}{cccc}
\hline & $\mathrm{T}_{1}$ & $\mathrm{X}_{1}$ & $\mathrm{~T}_{2}$ \\
\cline { 2 - 4 } & $\mathrm{T}_{1}$ & $\mathrm{X}_{2}$ & $\mathrm{~T}_{2}$ \\
\cline { 2 - 4 } & $\mathrm{T}_{1}$ & - & $\mathrm{T}_{2}$ \\
\hline
\end{tabular}

annotation:

M : Matching

$\mathrm{T}_{1} \quad$ : Group I, pretest anxiety and concentration

$\mathrm{T}_{1} \quad$ : Group II, pretest anxiety and concentration

$\mathrm{T}_{1} \quad$ : Group III, pretest anxiety and concentration

$\mathrm{X}_{1} \quad$ : Imagery training method

$\mathrm{X}_{2} \quad$ : Progressive Muscle Relaxation training method

$\mathrm{X}$. : Conventional training

$\mathrm{T}_{2} \quad$ : Group I, posttest anxiety and concentration 
$\mathrm{T}_{2} \quad$ : Group II, posttest anxiety and concentration

$\mathrm{T}_{2} \quad$ : Group III, posttest anxiety and concentration

The research sample, which consisted of 33 athletes, was pretested to determine the division of the group. 11 athletes as the experimental group I were given the imagery training program, the next 11 athletes as the experimental group II were given the progressive muscle relaxation exercise program, and the next 11 athletes as the control group. The group division process is carried out using ordinal pairing techniques to equalize the quality of each group. After dividing the groups, treatment (treatment) was given only to the experimental group. Group I with Imagery exercises and group II with Progressive Muscle Relaxation exercises. Meanwhile, group III (control group) was given conventional training.

The test instrument to measure the level of concentration is the grid concentration exercise test, while the anxiety test uses a sport anxiety scale. Data analysis in this study used a different test (t-test) and multivariate analysis of variance (MANOVA). In the calculation analysis using the program of statistical product and service solution version 22.0.

\section{RESULTS AND DISCUSSION}

Based on the data obtained, it can be concluded that there was a more significant increase in the two experimental groups compared to the control group. Concentration increased in both experimental groups I and II, the level of anxiety was more visible in the experimental group I, but based on the unequal mean results, this shows that the progressive muscle relaxation and imagery variables proved to have an effect on the three dependent variables but were relatively unequal. The results of the t-test of anxiety level variables are presented in Table 2.

Table 2. The t-test results of the anxiety level variable

\begin{tabular}{llc}
\hline & \multicolumn{1}{c}{ Anxiety variable } & Sig. (2-tailed) \\
\hline Pair 1 & Pretest-posttest progressive muscle relaxation & 0.000 \\
Pair 2 & Pretest-posttest imagery & 0.003 \\
Pair 3 & Pretest-posttest control & 0.081 \\
\hline
\end{tabular}

The results of the calculation of paired t-test on the provision of progressive muscle relaxation exercise by looking at the value of Sig. (2-tailed) 0.000 , it can be concluded that $\mathrm{Ho}$ is rejected and $\mathrm{Ha}$ is accepted because the value of Sig. $0.000<0.05$. In other words, there is a significant exercise effect from giving progressive muscle relaxation exercises to the level of anxiety. The results of the calculation of the paired t-test on the provision of Imagery exercises by looking at the value of Sig. (2-tailed) 0.003 , it can be concluded that Ho is rejected and $\mathrm{Ha}$ is accepted because Sig. $0.000<0.05$. In other words, there is a significant training effect from giving Imagery exercises to the level of anxiety. While in the control group the value of Sig. (2-tailed) 0.081, it can be concluded that Ho is accepted and $\mathrm{Ha}$ is rejected because the value of Sig. $0.000>0.05$. In other words, there is no significant effect between conventional exercise and anxiety levels. Furthermore, the results of the t-test on the concentration variable are presented in Table 3.

Table 3. The t-test results of the concentration variable

\begin{tabular}{llc}
\hline & \multicolumn{1}{c}{ Concentration variable } & Sig. (2-tailed) \\
\hline Pair 1 & Pretest-posttest progressive muscle relaxation & 0.000 \\
pair 2 & Pretest-posttest imagery & 0.000 \\
pair 3 & Pretest-posttest control & 0.171 \\
\hline
\end{tabular}

The results of the calculation of paired t-test on the provision of progressive muscle relaxation exercise by looking at the value of Sig. (2-tailed) 0.000 , it can be concluded that $\mathrm{Ho}$ is rejected and $\mathrm{Ha}$ is accepted because the value of Sig. $0.000<0.05$. In other words, 
there is a significant effect of giving progressive muscle relaxation exercises to increase concentration. The results of the calculation of the paired t-test on the provision of imagery training by looking at the value of Sig. (2-tailed) 0.000 , it can be concluded that Ho is rejected and $\mathrm{Ha}$ is accepted, because Sig. $0.000<0.05$. In other words, there is a significant effect of giving imagery training to increase concentration. While the results of the calculation of the paired t-test on the control group exercise (conventional exercise) by looking at the value of Sig. (2-tailed) 0.171, it can be concluded that Ho is accepted and Ha is rejected because the value of Sig. $0.000>0.05$. In other words, there is no significant effect between conventional training and the level of concentration.

Based on the results of the calculation of the difference between groups using the Multivariate Analysis of Variance, in the group row, a significant Wilks' Lambda value of 0.064 was obtained. So it can be said that the $p$ value $>0.05$. So based on this significance value, it can be concluded that there is no difference in the effect between the concentration variables and the level of anxiety together. Therefore, it can be concluded that neither of the two methods of mental exercise (imagery and progressive muscle relaxation) has a more effective effect on concentration and anxiety levels..

These results are in accordance with several previous studies that imagery training is very beneficial for improving the ability and strength of athletes (Buck et al., 2016), in preparing to appear confident, improving interpersonal skills, and controlling psychological symptoms, concentration, correcting mistakes, and even very useful for accelerating recovery from injuries suffered by athletes (Oh \& Choi, 2021). In addition, progressive muscle relaxation exercise is a form of mental exercise that can be used to increase concentration, increase speed and physical performance (Fekih et al., 2020), and specifically in soccer athletes is to improve their motoric skills (Zapała et al., 2021).

\section{CONCLUSION}

The results of the study showed that there was a significant effect of giving progressive muscle relaxation and imagery exercises to the level of anxiety in soccer players. However, it has no effect on conventional exercise modes. The provision of progressive muscle relaxation and imagery exercises also affects concentration in soccer players, and this does not apply to conventional training modes. In this study, we also found that there was no difference in the effect of the concentration variables and the level of anxiety together. Therefore, it can be concluded that neither of the two methods of mental exercise (imagery and progressive muscle relaxation) has a more effective effect on concentration and anxiety levels.

\section{RECOMMENDATION}

The recommendation from the results of this study is that mental training conduction (imagery and progressive muscle relaxation) is very important for soccer players as a nonphysical exercise mode that is very useful for reducing anxiety and increasing concentration.

\section{ACKNOWLEDGMENT}

This study is part of a novice lecturer research scheme, where all research funding is financed by the Ministry of Education and Culture of the Republic of Indonesia.

\section{REFERENCES}

Arifin, A. A. (2018). Meminimalisir Stres Belajar Siswa Melalui Teknik Meditasi Hening. Jurnal Bimbingan dan Konseling Terapan, 2(1). https://doi.org/10.30598/jbkt.v2i1.237

Benítez-Sillero, J. de D., Martínez-Aranda, L. M., Sanz-Matesanz, M., \& DomínguezEscribano, M. (2021). Determining Factors of Psychological Performance and Differences among Age Categories in Youth Football Players. Sustainability, 13(14), 7713. https://doi.org/10.3390/su13147713 
Buck, D., Hutchinson, J., Winter, C., \& Thompson, B. (2016). The Effects of Mental Imagery with Video-Modeling on Self-Efficacy and Maximal Front Squat Ability. Sports, 4(2), 23. https://doi.org/10.3390/sports4020023

Fekih, S., Zguira, M. S., Koubaa, A., Ghariani, I., Zguira, H., Bragazzi, N. L., \& Jarraya, M. (2020). The Impact of a Motor Imagery-Based Training Program on Agility, Speed, and Reaction Time in a Sample of Young Tennis Athletes during Ramadan Fasting: Insights and Implications from a Randomized, Controlled Experimental Trial. Nutrients, 12(11), 3306. https://doi.org/10.3390/nu12113306

Gao, Y., Fu, N., Mao, Y., \& Shi, L. (2021). Recreational Screen Time and Anxiety among College Athletes: Findings from Shanghai. International Journal of Environmental Research and Public Health, 18(14), 7470. https://doi.org/10.3390/ijerph18147470

Izgu, N., Gok Metin, Z., Karadas, C., Ozdemir, L., Metinarikan, N., \& Corapcioglu, D. (2020). Progressive Muscle Relaxation and Mindfulness Meditation on Neuropathic Pain, Fatigue, and Quality of Life in Patients With Type 2 Diabetes: A Randomized Clinical Trial. Journal of Nursing Scholarship, 52(5), 476-487. https://doi.org/10.1111/jnu.12580

Lefebvre, E., \& D'Angiulli, A. (2019). Imagery-Mediated Verbal Learning Depends on Vividness-Familiarity Interactions: The Possible Role of Dualistic Resting State Network Activity Interference. Brain Sciences, 9(6), 143. https://doi.org/10.3390/brainsci9060143

Mackereth, P. A., \& Tomlinson, L. (2010). Progressive muscle relaxationa remarkable tool for therapists and patients. In Integrative Hypnotherapy (pp. 82-96). Elsevier. https://doi.org/10.1016/B978-0-7020-3082-6.00008-3

Maharani, E. A. (2017). Pengaruh Pelatihan Berbasis Mindfulness terhadap Tingkat Stres pada Guru PAUD. Jurnal Penelitian Ilmu Pendidikan, 9(2), 100. https://doi.org/10.21831/jpipfip.v9i2.12919

Malm, C., Jakobsson, J., \& Isaksson, A. (2019). Physical Activity and Sports-Real Health Benefits: A Review with Insight into the Public Health of Sweden. Sports, 7(5), 127. https://doi.org/10.3390/sports7050127

Oh, D. S., \& Choi, J. D. (2021). Effects of Motor Imagery Training on Balance and Gait in Older Adults: A Randomized Controlled Pilot Study. International Journal of Environmental Research and Public Health, 18(2), 650. https://doi.org/10.3390/ijerph18020650

Ortega Vila, G., Robles Rodríguez, J., Giménez Fuentes-Guerra, F. J., Franco Martín, J., Jiménez Sánchez, A. C., Durán González, L. J., \& Abad Robles, M. T. (2020). Competitive Anxiety in Young Basketball Players from the Real Madrid Foundation. Sustainability, 12(9), 3596. https://doi.org/10.3390/su12093596

Smith, A., Haycock, D., Jones, J., Greenough, K., Wilcock, R., \& Braid, I. (2020). Exploring Mental Health and Illness in the UK Sports Coaching Workforce. International Journal of Environmental Research and Public Health, 17(24), 9332. https://doi.org/10.3390/ijerph17249332

Zapała, D., Zabielska-Mendyk, E., Cudo, A., Jaśkiewicz, M., Kwiatkowski, M., \& Kwiatkowska, A. (2021). The Role of Motor Imagery in Predicting Motor Skills in Young Male Soccer Players. International Journal of Environmental Research and Public Health, 18(12), 6316. https://doi.org/10.3390/ijerph18126316 